Glacial sedimentology interpretation from borehole image log Example from the Late Ordovician deposits, Murzuq Basin (Libya)

Moreau, Julien; Joubert, Jean-Bernard

Published in:

Interpretation (Flushing)

DOI:

10.1190/INT-2015-0161.1

Publication date:

2016

Document version

Publisher's PDF, also known as Version of record

Citation for published version (APA):

Moreau, J., \& Joubert, J-B. (2016). Glacial sedimentology interpretation from borehole image log: Example from the Late Ordovician deposits, Murzuq Basin (Libya). Interpretation (Flushing), 4(2), B1-B16.

https://doi.org/10.1190/INT-2015-0161.1 


\title{
Glacial sedimentology interpretation from borehole image log: Example from the Late Ordovician deposits, Murzuq Basin (Libya)
}

\author{
Julien Moreau ${ }^{1}$ and Jean-Bernard Joubert ${ }^{2}$
}

\begin{abstract}
In the Murzuq Basin, the Late Ordovician glaciogenic succession forms a very complex clastic reservoir system. Although the structural setting is simple, the architecture of the stratigraphic succession is particularly intricate, and conventional wireline logs display rather homogeneous signatures. However, when exposed, the glaciogenic sedimentary succession indicates a very large range of depositional environments and clear stratigraphic changes. Based on high-quality processing and interpretation of wireline microresistivity image logs over a single well, our method allows the precise recognition of the internal sedimentary structures and supports the interpretation of the depositional environments within the Late Ordovician succession. During interpretation, it is possible to draw a descriptive sedimentological log, similar to a standard log from cores or outcrops. The image log is interpreted like a regular sedimentary log and compared to an outcrop analog from the nearby outcrop area of Ghat. The success of the well analysis resides in the quality of the borehole image log, permitting the recognition of sandstone grain sizes, textures (facies), and sorting. In addition, crucial information is extracted from the identification of glacial surface and ice-flow orientations, which, combined with the recognition of major transgressive events, allows the recognition and correlation of glacial-type stratigraphy. As in the modern Pleistocene glaciation, stadial/interstadial and glacial/interglacial stages are identified from resistivity imaging of the Libyan Ordovician succession. In addition to the unprecedented potential of correlation between wells within the basin, the sedimentary information extracted from the borehole image log provides important insights on the paleogeographic context of the basin and thus on the exploration potential of the prolific Ordovician-Silurian petroleum system.
\end{abstract}

\section{Introduction}

Well petrophysical data interpretations are crucial in petroleum exploration and production. They are routinely conducted and provide essential insights on the quality of the rocks involved in the petroleum system. However, in some sedimentary environments, the acoustic and the petrophysical measurements are not able to provide sufficient diagnostic information to characterize reservoir properties and geometries. The limits of the use of standard logs arise from (1) the possible confusion between formations with similar sand/shale ratios (e.g., basal lag with large shaley clasts formations and sandrich debris flow) and (2) the limited resolution and the smearing effect of standard logs, which do not provide any detailed sedimentological information of the penetrated strata. On the contrary, bed thickness, bed contacts, or postdepositional events, which are important sedimentological data, can be observed on the texture of borehole images (Schlumberger, 1985). This information is obtained by the categorization and orientation of the surfaces that provide data at a similar scale as core descriptions.

The North African Ordovician glaciogenic reservoirs are architecturally complex and have a rather homogeneous signature on well logs and cores, in particular for the lower stratigraphic levels (Le Heron and Craig, 2008). However, in the outcrop, the equivalent rocks highlight a large panel of sedimentary facies and architectures, resolving the stratigraphy and the paleodepositional environments (Blanpied et al., 2000; Ghienne et al., 2003, 2007a, 2010; Le Heron et al., 2004; Moreau, 2005, 2011; Le Heron and Craig, 2008; Girard et al., 2012a, 2012b).

In the Murzuq Basin (Libya; Figure 1), the homogeneous signature of the conventional open-hole logging

\footnotetext{
${ }^{1}$ University of Copenhagen, Department of Geosciences and Natural Resource Management, Copenhagen, Denmark. E-mail: moreau.juli1@gmail .com.

${ }^{2}$ CSTJF Pau, Exploration Technologies, Sedimentology and Structural Interpretation Department, Pau, France. E-mail: jean-bernard.joubert@ total.com.

Manuscript received by the Editor 25 September 2015; revised manuscript received 16 December 2015; published online 18 April 2016. This paper appears in Interpretation, Vol. 4, No. 2 (May 2016); p. B1-16, 12 FIGS., 2 TABLES.

http://dx.doi.org/10.1190/INT-2015-0161.1. @ The Authors.Published by the Society of Exploration Geophysicists and the American Association of Petroleum Geologists. All article content, except where otherwise noted (including republished material), is licensed under a Creative Commons Attribution 4.0 Unported License (CC BY$\mathrm{SA})$. See http://creativecommons.org/licenses/by/4.0/. Distribution or reproduction of this work in whole or in part commercially or noncommercially requires full attribution of the original publication, including its digital object identifier (DOI). Derivatives of this work must carry the same license.
} 
tools results from the lack of large petrographic contrasts between the units (Figure 2). In this area, the glaciogenic succession is mainly composed of mature sands (eroded from rather homogeneous sandy preglacial formations), diamictites, and some thin shale intervals (Moreau, 2005,2011 ). By definition, diamictites are a mixture of different grain sizes, showing poor contrast with the sand-dominated succession. The finer grained deposits have few clay minerals, so there is less potential of polarization or conductivity contrasts with mature sands (mainly quartz and heavy mineral here), thus limitating the efficiency of electromagnetic response tools. In addition to the original homogeneous sandy composition, quartz overgrowths are widespread, further impeding the variability of the borehole geophysics signals (El-Ghali et al., 2006). Consequently, high-resolution microresistivity borehole tools are needed to image the subtle petrographic changes of the glaciogenic sedimentary succession.

Linking the outcrop observations with subsurface data is one of the objective of this study. The work illustrates a method based on a high-quality borehole resistivity imager tool to analyze the prolific Libyan Late Ordovician reservoir succession in the Murzuq Basin (Figure 1). The realization of this study necessitates several steps starting from the calibration of the tool to the paleodepositional environment reconstruction. This work aims at presenting a comprehensive workflow for the analysis of glaciogenic succession from borehole image log interpretation with the processing used, the resulting images, and the deduced interpretations.

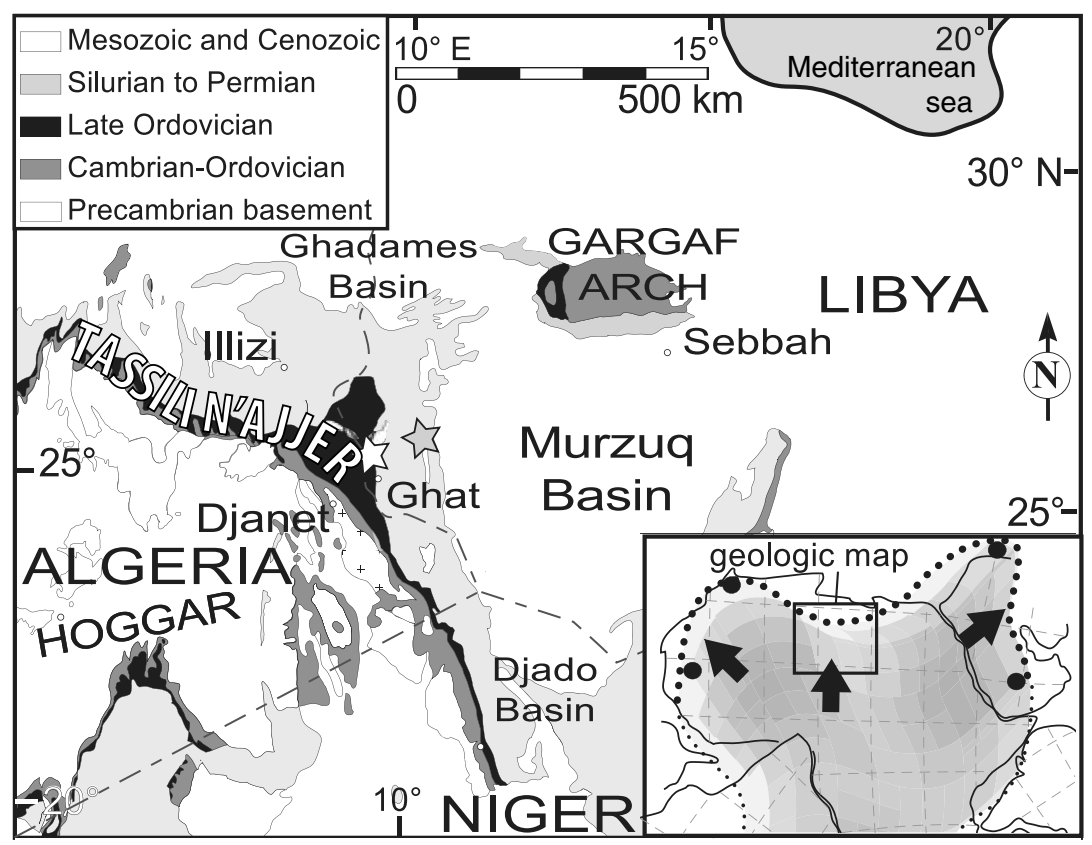

Figure 1. Geologic map of the area and reconstruction of the ice-sheet areal extent during the Ordovician glacial maximum (modified from Moreau, 2011). The white star is the outcrop analog section, and the gray star is the position of the studied well, modified from Moreau (2011). Notice that the outcrop and subsurface logs are perpendicular to the main ice flow, therefore in a similar paleogeographic setting.

\section{Geologic and glaciological settings}

During the Lower Paleozoic, the North African platform was a part of the supercontinent Gondwana. The platform is considered as a tectonically stable cratonic domain from the Mid-Ordovician (post-Floian) to Late Silurian (pre-Pridolian) times (Beuf et al., 1971; Boote et al., 1998; Coward and Ries, 2003; Eschard et al., 2005; Galeazzi et al., 2010; Ghienne et al., 2013). During this period, the area dipped gently toward the north-northwest and experienced relatively low subsidence rates. The present (actual) geometry of the Murzuq Basin is principally due to Devonian, Carboniferous, and Cretaceous tectonic events (Boote et al., 1998; Coward and Ries, 2003).

North Africa was situated at a high latitude during the Late Ordovician (approximately S80 and S65; Torsvik and Cocks, 2013). The supercontinent supported a continental-scale glaciation that is recorded throughout Western Gondwana (e.g., Ghienne et al., 2007b; Figure 1). During the Late Ordovician glaciation, ice sheets grew and decayed repeatedly on the West Gondwana platform (Sutcliffe et al., 2000; Ghienne et al., 2007b; Le Heron and Craig, 2008). The ice sheets were similar to the Pleistocene ice sheets in that they contained fast and slow ice-flow areas, ice streams, and ice domes (Moreau et al., 2005, 2007; Ghienne et al., 2007b; Le Heron and Craig, 2008; Moreau, 2011).

The studied glaciogenic succession rests unconformably on older strata represented by Cambrian (Hasawnah Formation) and Lower Ordovician sandstones (Ash Shaybiyat Formation) and is draped by Early Silurian shales (Iyadhar and Tanzuft Formations; Bellini and Massa, 1980; Klitzsch, 1981; Radulović, 1984; Lüning et al., 2000; Štorch and Massa, 2006; Moreau, 2011). In the studied area, the Middle Ordovician sandstones (Hawaz Formation) have been completely eroded away by the successive glacial advances and recessions (Moreau, 2005, 2011). In addition to the regular sedimentologic work, the exposures of glaciogenic rock in the Ghat area allow us to perform geomorphological analyses (Moreau et al., 2005; Le Heron and Craig, 2008; Moreau, 2011; Moreau and Ghienne, forthcoming). The geomorphology highlights that the area was under ice stream activity during most of the glaciation (Moreau et al., 2005). Furthermore, the ice streams were extending laterally up to $350 \mathrm{~km}$ west of the Ghat town (Moreau et al., 2007). Consequently, most of the subsurface of the Murzuq Basin was repetitively under ice stream activities during the Late Ordovician. The local glaciogenic stratigraphy intends to 
mimic the organization of the Pleistocene glacial stratigraphy that uses glacial and interglacial periods containing glacial and interglacial stages (Ghienne et al., 2007b; Moreau, 2011). In the Murzuq Basin, the glaciogenic stratigraphy is organized in glacial cycles (periods) containing glacial phases (stages; Moreau, 2011). The glacial cycles are based on regional glacial erosion surfaces and topped by postglacial transgressive deposits. A glacial cycle records the ice-sheet evolution from the first advance to the withdrawal from the basin and the establishment of nonglacial depositional conditions (Moreau, 2011). A glacial phase corresponds with a higher frequency advance recession of the ice sheet within a glacial cycle.

The multiple glacial erosion surfaces formed characteristic large-scale geomorphological landforms, the glacial ridges (Figure 3c; Moreau et al., 2005). The glacial ridges often form remnant highs flooded after the Silurian postglacial transgression (Lüning et al., 2005; Moreau et al., 2005; Moreau, 2011). The glacial ridges are potential stratigraphic traps laterally sourced by the Early Silurian source rock ("hot" shales; Lüning et al., 2005; Moreau, 2011). This study focuses on the comparison between a well drilled through one glacial ridge and an outcrop analog in the Ghat area $(50 \mathrm{~km}$ toward the west-southwest; Figure 1). The glacial ridges have a complex internal architecture, with a highly variable composition and reservoir qualities that are often difficult to assess (Moreau et al., 2005; Ghienne et al., 2007b; Le Heron and Craig, 2008; Moreau, 2011; Figure 3a and $3 \mathrm{c})$.

Two main types of stratigraphic surfaces were used at regional scale in the glacial series of the Murzuq Basin: glacial surfaces and transgressive surfaces (Moreau, 2005, 2011; Ghienne et al., 2007b). An assemblage of erosional and depositional features represents these surfaces. Glacial assemblages (GAs) are directly associated with ice-sheet activity (sub- and proglacial deformation and associated sedimentation). The transgressive assemblages (TAs) correspond to major postglacial transgression and are due to complete ice-sheet retreat from the basin (equivalent to a Quaternary interglacial). In terms of sequential stratigraphy, a glacial depositional sequence (GS) is limited at the base by a GA and a TA bound at the top of a glacial cycle (containing a couple of GSs). Typically, the GSs are formed by a basal diamictite with ice-rafted debris (IRD) evidence, which is overlaid by a fluvio-deltaic unit (Figure 3). The nature of the fluvio-deltaic sequence varies between sequences as the position of the source, the available space, and the relative position to ice masses during postglacial times (Figure 3). Located on its western rim, the Ghat area presents the best preserved stratigraphic record of the Murzuq Basin. To analyze the drilled sedimentary succession presented in this study, a well-preserved outcrop analog of a glacial ridge in the same paleogeographic setting is described.

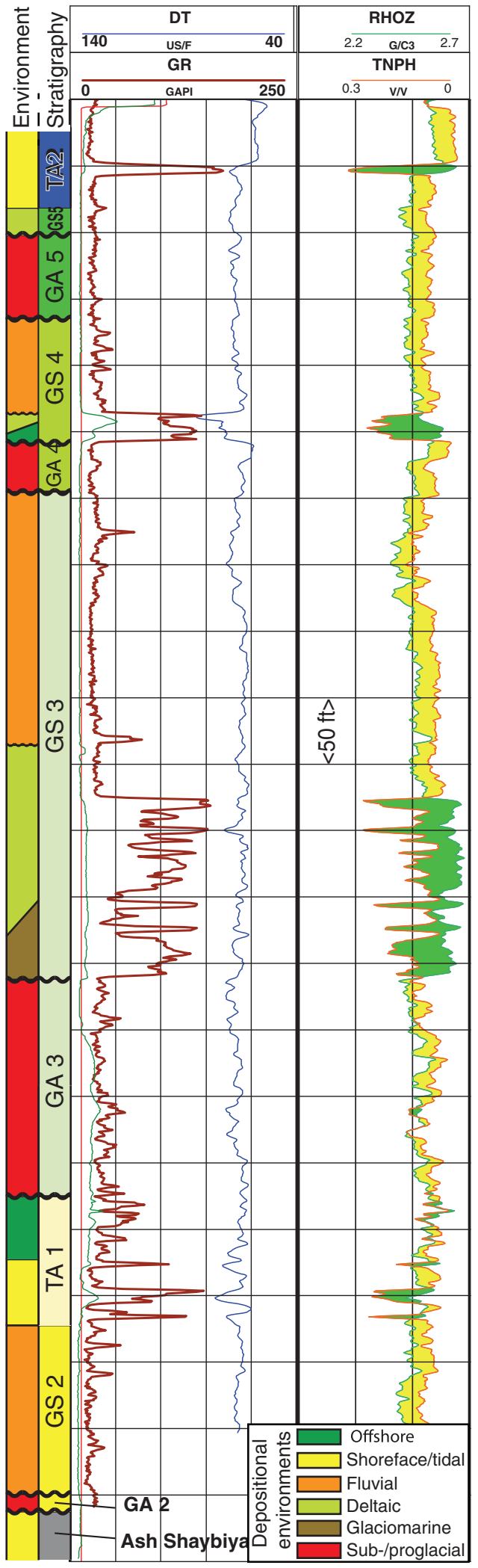

Figure 2. Wireline logs from the imaged well with sedimentary and paleoenvironmental interpretations made with FMI analysis (Figure 12; this study). Notice that most of the stratigraphic surfaces are not marked on the electric logs, and most of the radioactive/shaley intervals can lead to confusion because they are from different depositional environments and mark different parts of the GSs (no stratigraphic value). 


\section{The outcrop analog stratigraphic succession (northwest Ghat glacial ridge)}

The glacial ridge situated directly to the northwest of the town of Ghat constitutes the closest analog of the studied well data (Figure 1; Moreau, 2005, 2011; Moreau et al., 2005; Joubert et al., 2007). The description of this outcrop analog intends to image the variability of the sedimentary units to capture all the possible units drilled and imaged (Figure 3; Table 1).
In the Ghat area, the stratigraphic succession is formed of two glacial cycles (Moreau, 2005, 2011). The first glacial cycle is preserved in the glacial troughs and composed of two GSs (GS1 and GS2) and the first TA (TA1). Only the top of the GS2 and the TA1 is observed in the core of glacial ridges (Figure 3a). The second glacial cycle contains three GSs (GS3, GS4, and GS5) and the last TA (TA2; Figure 3a). In the glacial ridges are preserved GS3, GS4, and TA2. The GS5 is restricted a)

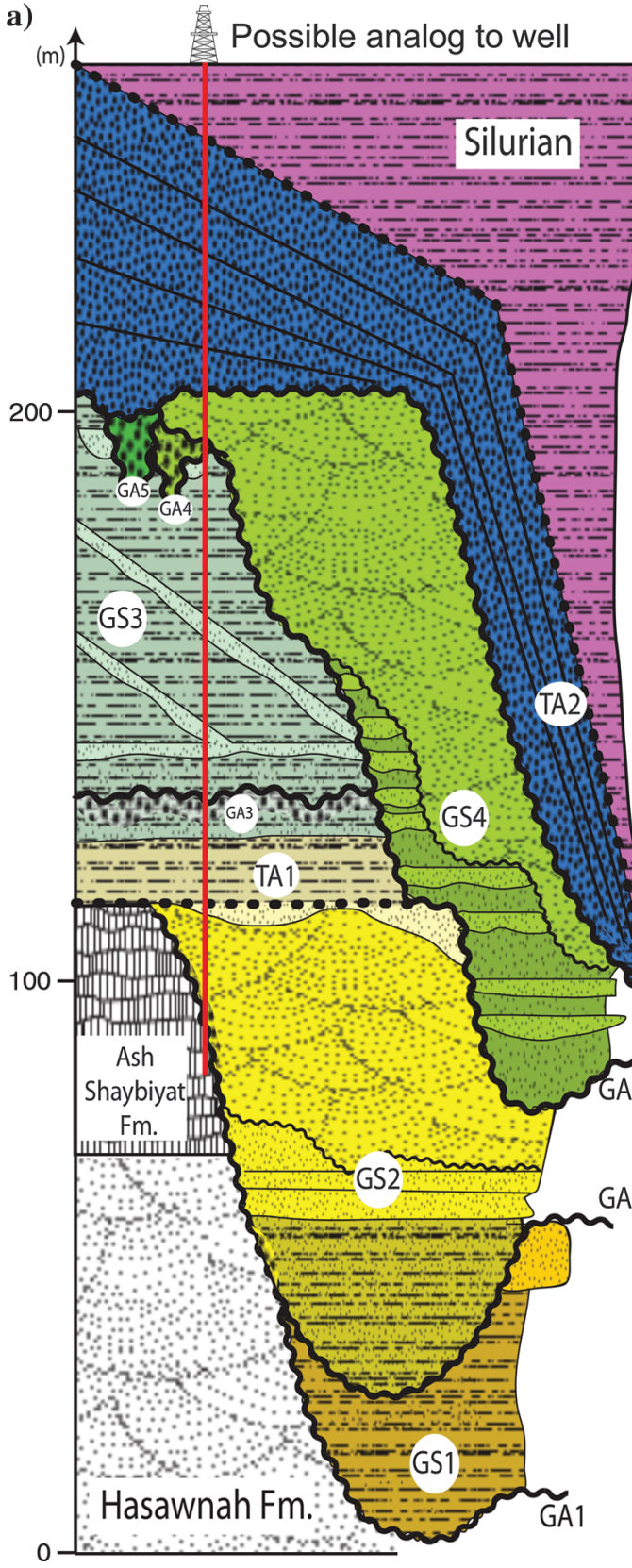

b)

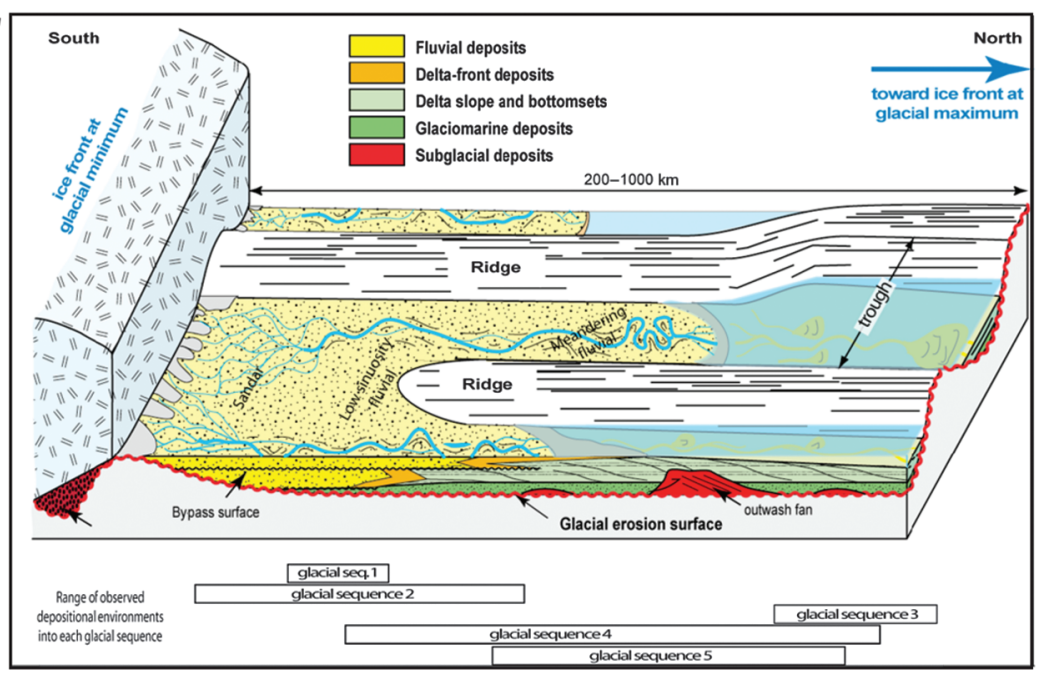

Figure 3. Outcrop analog for the subsurface of the Murzuq Basin. (a) Synthetic log of the Ghat area glaciogenic succession, modified from Moreau (2011). The TA (transgressive deposits marking the end of a glacial cycle), GA (subglacial erosion or deposition and/or proglacial deposition), and GS (aggrado-progradational depositional system associated with the stabilization of the ice sheet south of the Ghat-Tikiumit area). The position of the potential outcrop analog is figured by the derrick symbol and the red wellpath. (b) Depositional environment model of type GS after ice retreat (postglacial conditions; modified from Moreau, 2005). (c) Outcrop section illustrating the architecture of the glaciogenic succession directly north of the Ghat town and particularly the presence of glacial ridges and troughs (modified from Moreau et al., 2005). 
to underfilled glacial troughs (Figure 3; Moreau, 2011). The proglacial part of GA5 can drape and conceal the remnant topography but does not form sensu stricto a glacial ridge (Moreau, 2011).

The sedimentary succession of the glacial ridge preserved northwest of the town of Ghat is the closest observed analog to the imaged well. The descriptions are therefore limited to this setting in addition to key elements that would permit their identification on image log (Figure 3; Table 1; Moreau, 2005; Ghienne et al., $2007 \mathrm{~b}$ ). The core of the glacial ridge is formed by the Ash Shaybiyat Formation (Lower Ordovician; Radulović, 1984). The formation is preglacial and composed of crudely bedded tabular sandstone beds. It is characterized by an intense bioturbation of Skolithos type (also called Tigillites in the area; e.g., Beuf et al., 1971).

Laterally to the preglacial formation, and incising in it, can be found the GA2. The GA2 is made of poorly sorted very coarse-grained to granule-sized sandstones including rounded blocks. The GA2 forms a discontinuous unit $<5 \mathrm{~m}$ thick conformable to the erosional surface. Sheath folds and striations are common in GA2. The long axis of the folds, the intraformational striations, and the glacial lineations associated with this surface consistently indicate an ice flow toward N320. Only the upper part of GS2 is preserved in the glacial ridges, and the thickness does not exceed $20 \mathrm{~m}$ there. The unit is formed of coarse-grained sandstones with occasional floating granule-sized clasts marked by meter-high trough cross beddings within bars and channels.

The TA1 is slightly incising in the Ash Shaybiyat Formation and the GS2 with occasional $<8 \mathrm{~m}$ deep, sinuous channels (Figure 3). The channels are constituted of thinly laminated, well-sorted fine-grained sandstones containing Diplocraterion ichnofossils. The channels are eroded by a flat surface, which is associated with a granule lag. The lag is overlaid by the upper part of TA1, formed of approximately $10 \mathrm{~m}$ thick laminated shales (poorly exposed).

The shales are conformably overlaid by $\mathrm{a}<10 \mathrm{~m}$ of silty diamictite with sandstone lenses and isolated pebbles corresponding to the base of GA3 (second glacial cycle). The diamictite is incised by channels containing small sandstone pipes and glaciotectonic thrust planes. The channels form the top of GA3 and are filled by medium-grained sandstones to conglomerates; one esker has also been observed within this assemblage. Underlying and within the GA3, the sediments are affected by step fractures (Riedel shears; Biju-Duval et al., 1974; Deynoux and Ghienne, 2004). The GS3 conformably overlay the GA3 with approximately $5 \mathrm{~m}$ of silty diamictite containing isolated pebbles and granule-sized sand grains. The diamictite is overlaid by an approximately $65 \mathrm{~m}$ thick coarsening-upward sequence with siltites to very finegrained sandstones. The sequence is locally interrupted by meter-thick tabular fine-grained sandstone beds.

Table 1. Sedimentary unit descriptions.

\begin{tabular}{|c|c|c|c|c|c|c|c|c|}
\hline & & $\begin{array}{l}\text { Glacial } \\
\text { ridge units }\end{array}$ & Extent & Petrography & Sorting & $\begin{array}{c}\text { Characteristic } \\
\text { sedimentary features }\end{array}$ & Bioturb & $\begin{array}{l}\text { Associated } \\
\text { deformation }\end{array}$ \\
\hline \multirow[t]{10}{*}{$\begin{array}{l}\text { Glacial } \\
\text { cycle }\end{array}$} & 2 & TA2 & Widespread & $\begin{array}{l}\text { Very coarse-grained } \\
\text { sandstones }\end{array}$ & Good & Large X beds & Intense & No \\
\hline & 2 & GA5 & In tunnel channels & Silts to block & Poor & $\begin{array}{c}\text { Diamictite } \\
\text { laminated/massive } \\
\text { sandstones, blocks }\end{array}$ & No & $\begin{array}{l}\text { Shear planes, } \\
\text { locally fold and } \\
\text { thrust belt }\end{array}$ \\
\hline & 2 & GS4 & $\begin{array}{l}\text { Rare, preserved } \\
\text { on the sides }\end{array}$ & $\begin{array}{l}\text { Medium-grained } \\
\text { sandstones }\end{array}$ & Good & $\begin{array}{l}\text { Tabular beds, } \\
\text { climbing ripples }\end{array}$ & No & No \\
\hline & 2 & GA4 & In tunnel channels & $\begin{array}{l}\text { Medium-grained } \\
\text { sandstones to } \\
\text { pebbles }\end{array}$ & Medium & $\begin{array}{l}\text { Matrix supported } \\
\text { clasts, diamictite, } \\
\text { injections }\end{array}$ & No & Shear planes \\
\hline & 2 & GS3 & Extensive & $\begin{array}{l}\text { Silts with fine-grained } \\
\text { sandstones beds }\end{array}$ & Good & $\begin{array}{c}\text { Sandy clinoforms } \\
\text { with climbing ripples }\end{array}$ & Possible & No \\
\hline & 2 & GA3 & Discontinuous & $\begin{array}{l}\text { Medium-grained } \\
\text { sandstones to } \\
\text { conglomerates }\end{array}$ & Medium & $\begin{array}{c}\text { Channels, eskers, } \\
\text { pipes }\end{array}$ & No & Thrusts \\
\hline & 1 & TA1 & Extensive & $\begin{array}{l}\text { Medium- to fine-grained } \\
\text { sandstones topped by } \\
\text { shales }\end{array}$ & Good & $\begin{array}{l}\text { X-bedded sandstones } \\
\text { in channels, } \\
\text { laminated shales }\end{array}$ & $\begin{array}{c}\text { In the } \\
\text { sandstones }\end{array}$ & No \\
\hline & 1 & GS2 & Locally preserved & $\begin{array}{l}\text { Coarse-grained } \\
\text { sandstones }\end{array}$ & Bimodal & $\begin{array}{l}\text { Large X beds, } \\
\text { climbing dunes }\end{array}$ & No & No \\
\hline & 1 & GA2 & Locally preserved & $\begin{array}{c}\text { Coarse-grained } \\
\text { sandstones to granules }\end{array}$ & Medium & Large blocs & No & Sheath folds \\
\hline & 1 & $\begin{array}{l}\text { Ash } \\
\text { Shaybiyat } \\
\text { Formation }\end{array}$ & Extensive & $\begin{array}{l}\text { Coarse-grained } \\
\text { sandstones }\end{array}$ & Good & $\begin{array}{l}\text { Rough tabular } \\
\text { bedding }\end{array}$ & Skolitos & No \\
\hline
\end{tabular}


The beds form low-angle clinoforms merging at the bottom of the sequence. The beds have an erosive base and are relatively well sorted. They present repetitive successions of sequences with climbing ripples at base and planar laminations with occasional fluid escape structures at top. The sequences alternate with massive sandstones containing pebble-sized clasts of siltstones. The top of GS3 shows occasional isolated to amalgamated 2-3 m thick channels within the fine-grained ground mass. The channels bear the same sedimentary structures and grain size as the clinoforms.

The GA4 incises within GS3. The GA4 is marked by poorly sorted cross-stratified medium-grained sandstones and matrix-supported pebble-sized sandy conglomerates organized in tabular beds, which are contained in tunnel channels ( $<50 \mathrm{~m}$ deep; Moreau et al., 2005). The GA4 can also be reduced to the imprint of deformation structures in the underlying sequences (shear planes and step fractures; Deynoux and Ghienne, 2004; Le Heron et al., 2005) and sand injections (pipes and dykes) and liquefaction features. The striations and lineations of GA4 indicate a flow toward the N340. Only the uppermost part of the GS4 is observed in the glacial ridge, and it consists of well-sorted medium-grained sandstones. The sandstones are organized in bars and channels with the frequent presence of planar cross-stratifications, climbing ripples, and parallel laminations organized in tens of centimeter se- quences. The upper part occasionally shows coarsegrained sandstone channel incisions.

The GA5 is incising in the underlying sequences and is associated with the development of tunnel channels at the top of the glacial ridge. The grain-sized GA5 is variable depending on the channel but usually shows poorly sorted medium-grained to very coarse-grained sandstones and occasional pebble-sized conglomerates. The GA5 shows intraformational striations and deformations and cross-stratifications. The deformation shows a flow toward N350 to N60. The TA2 directly drape GA5 and is formed of very coarse-grained sandstones with $20-100 \mathrm{~cm}$ cross-stratifications. The TA2 is intensively bioturbated and terminates by a granulesized lag marking the boundary between the Ordovician and the Silurian (Moreau, 2011).

Based on the different outcrop studies in the Murzuq Basin, the variation of depositional environments preserved within the glacial ridge can be established (Radulović, 1984; Le Heron et al., 2004; Moreau, 2005, 2011; Moreau et al., 2005; Ghienne et al., 2007b; Le Heron and Craig, 2008). The Ash Shaybiyat Formation is made of upper shoreface to beach deposits. The GA2 is a deformation till formed with glaciofluvial sediments. The overlaying sequence (GS2) is of fluvial origin. The TA1 marks a two-step transgression with channel fills of tidal origin at base, an acceleration of the transgression marked by a

Table 2. Curves checking list.

Curve types

Control and checking

Calipers

Hole deviation

Navigation records

\section{$\mathrm{A} Z$-1 (fast acceleration channel) Relative bearing - pad one azimuth \\ Tensions - logging speed Pad pressure}

Microresistivity curves

For acoustic tools

Hole scarring

Artifacts
Plotted in opposite scale and must show reasonable similarity with other caliper logs, control the borehole wall, and the opening of the tool arms.

Coherence with the driller's deviation, elimination of speed artifacts.

The basic principle of downhole inclinometer measurements is to accurately define the axes of the tool system with respect to the earth's gravity and magnetic fields. Accelerometer data: plot AX/AY: ring (centered to zero), plot $\mathrm{A} X / \mathrm{A} Z$ : horizontal line $z=9.81$, and plot $\mathrm{A} Z / \mathrm{A} Y$ : straight line $z=9.81$. Magnetometer data: plot $\mathrm{F} X / \mathrm{F} Y$ : ellipse before correction $(\mathrm{F} Y=\mathrm{F} Y \times$ field norm.) and a circle centered to zero after, plot $\mathrm{F} Y /$ $\mathrm{FZ}$ : horizontal line, and plot $\mathrm{F} Z / \mathrm{F} X$ : straight line.

For a deviated well, the circles become arcs of circles underlining the absence of tool rotation.

Close to $9.81 \mathrm{~m} / \mathrm{s}^{2}$ in a vertical well, in accordance with deviation angle: decreasing while deviation angle increases; for a deviated well, $9.81=\mathrm{A} Z-1 / \cos (\mathrm{DEVI})$; DEVI $=$ hole deviation angle from vertical.

Editing values at the bottom of the tool string and/or at the arms and/or at the acoustic transmitter and at the telemetry unit. This allows us to control the various and variable measurement point depth offset with the tool sketch and the absence of tool rotation in the hole (not exceeding one turn for $10 \mathrm{~m}$ ), relative bearing = rotation in plane normal to tool axis relative to the top of hole (stable in high deviation wells).

The values must be edited at the surface and in the hole, control the overpull and jamming. The cable speed at the surface and the tool velocity in the hole must be within the range of the recommendations.

Stable and indicating a good opening of the arms (caliper >; diameter tool); the pressure must be sufficient to have a good contact for the sensors to the formation.

Good depth matching pad-flap (if FMI) or pad-pad (dual-Oil-Base MicroImager), good activity of the sensors, resistivity conform with the fluids, correlate to each other, good contact with the formation in caving, absence of the "yo-yo effect," detect dead sensors.

Good agreements between the features observed in the amplitude and the traveltime images are indicative of good-quality logs.

List of all the detectable signatures, e.g., a key seat on the acoustic image gives the direction of the deviation, and the downhole is with $180^{\circ}$ high side (or top of hole).

List of all the artifacts during acquisition, processing, and others seen. 
lag, and a calm offshore environment with the deposition of fines. Glaciomarine conditions are reestablished at the base of GA3 with the formation of a rainout till, associated with the second glacial cycle ice readvance. The upper coarse-grained part of GA3 marks the presence of ice in the area. Low ice motion and a sub-buoyant ice sheet with occasional meltwater channel incisions and fills are inferred. The ice recession is marked by the base of the GS3 with the deposition of a rainout till. The depositional system is then prograding in a marine environment. A deltaic system develops, marked by sandy clinoforms fed by channels in the shallower parts. The deltaic construction involves lowand high-density gravity flows with turbiditic sequences and sandy mass flows, respectively. It is supposed that the delta is fed by a fluvial system not directly by the ice margins (no dropstone). The GA4 is associated with the peak glaciation and is mainly recorded by subglacial deformation structures; however, tunnel channels locally occur. The GS4 is interpreted as a high-energy aggrading fluvial system, braided to low sinuous. The GA5 is marked not only by subglacial deformations but also by a dense network of subglacially filled tunnel channels. The TA2 is a tidal deltaic system. The overlaying Silurian shales sealing the Ordovician units are deposited in an offshore shelf setting.

A sedimentary environment with specific sedimentary deposits characterizes each of the depositional units identified in the northwest Ghat glacial ridge (Figure 3). The characteristics of the analog glaciogenic succession are summarized in Table 1 . The units can be partially preserved or locally completely eroded (Figure $3 \mathrm{a}$ and $3 \mathrm{c}$ ). Therefore, the recorded sedimentary succession from a well (1D) might be slightly different than the synthesis presented as an analog (Figure 3).

\section{Data and processing Data}

The outcrop data result from three months of fieldwork in the vicinity of the Ghat town and from the interpretation of remote sensing data (Moreau, 2005, 2011; Moreau et al., 2005; Ghienne et al., 2007b; Moreau and Ghienne, forthcoming). The area has been consciously investigated based on approximately 50 sedimentary $\log$ s, the construction of several regional

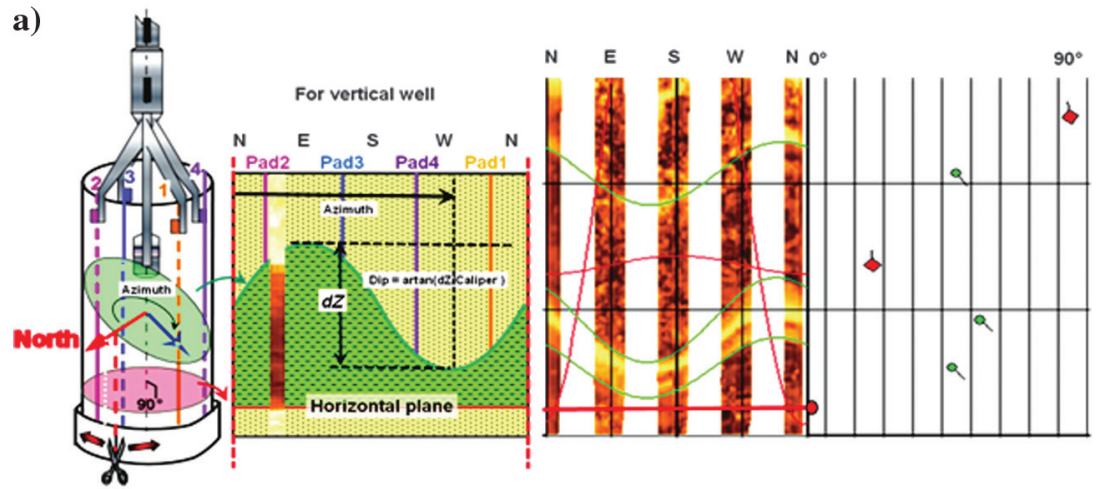

b)

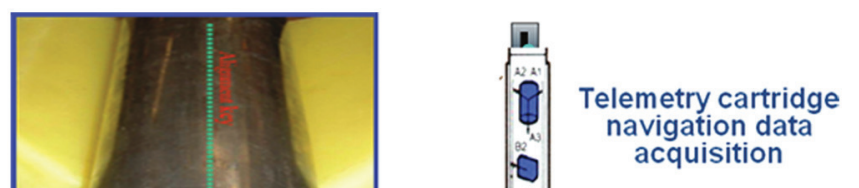
acquisition

Alignment groove mark in the same axis as Pad 1

Figure 4. Image tool and dip orientation principles. (a) While logging, tool pads are in contact with the formation; each pad has electrodes that provide resistivity curves. Dips are obtained from correlations between these resistivity curves. The intersection between a tilted plane and a cylinder is an ellipse. If the cylinder is projected on a plane, the ellipse becomes a sine wave. Its amplitude (height) $d Z$ is a function of the dip angle. The azimuth is calculated based on the orientation of the crests of the sine wave. Two vertical lines on borehole walls represent a plane parallel to the well axis. A straight horizontal line figures a plan strictly perpendicular to the well. (b) Navigation data are used for borehole 3D geometry, tools orientation, dip computation, and speed corrections. The basic principle of downhole inclinometer measurements is to accurately define the axes of the tool system with respect to the earth's gravity and magnetic fields. Tool position and orientation are defined by measurements from an accelerometer (three axis) and three magnetometers: in the $x$-direction: gives Pad-1Azi, tool body, and master calibration line azimuth, in the $z$-direction: along the tool axis and normal to $x$, and in the $y$-direction: normal to $x$ and $z$ directions. The $\mathrm{A} x, \mathrm{~A} y$, and $\mathrm{A} z$ refer to the accelerometer data in the $x$-, $y$-, and $z$-axes, respectively. The $\mathrm{F} x, \mathrm{~F} y$, and $\mathrm{F} z$ refer to the magnetometer data in the $x$-, $y$-, and $z$-axes, respectively. 
cross sections, and finally the building of a 3D sedimentary model of the glacial ridge (Moreau, 2005; Moreau et al., 2005; Ghienne et al., 2007b; Moreau, 2011). The depositional environments have been established, and a stratigraphic framework is applicable at the Murzuq Basin scale (Moreau, 2011).

Well data consist of a set of wireline logs including a high-resolution microresistivity imaging tool, the fullbore formation microimager (FMI; Figure 1). In addition to the imager tool, conventional wireline tools have been used (calipers, gamma rays, neutron porosity, formation density, and sonic logs; Figure 2). The imager tool is marketed by Schlumberger. It is used in water-based mud-drilled wells, and its 192 electrodes, distributed on four pads and four retractable flaps, measure the resistivity of the encountered formations. The final resistivity image represents, in an 8.5 in hole, $80 \%$ of the borehole walls. In this study, the well path was vertical and the image interpretation was realized before core sedimentary log and successfully quality checked later on.

\section{Processing workflow}

Before performing the sedimentologic study of the borehole images and the comparison with known outcrops, a comprehensive processing and quality control of the well data should be realized. The aim of the method description is to clarify the image data set and provide a checklist making it possible to interpret them in all confidence. Therefore, a basic methodology for image log interpretation goal is provided and a summary of all the curves or parameters to be checked and plotted to control logging conditions (Table 2). It includes understanding images and dips and some tips to detect pitfalls and rules for image observations. A borehole image log is not a picture or a photograph of the well but a "map" of the borehole walls using a color chart that implies the measure of formation properties related to electrical or acoustic (in the case of sonic tools) contrasts in relation to sediment heterogeneities (depositional or tectonic). Figure 4 illustrates how an image log is obtained for a pad tool imager in a vertical borehole. a)
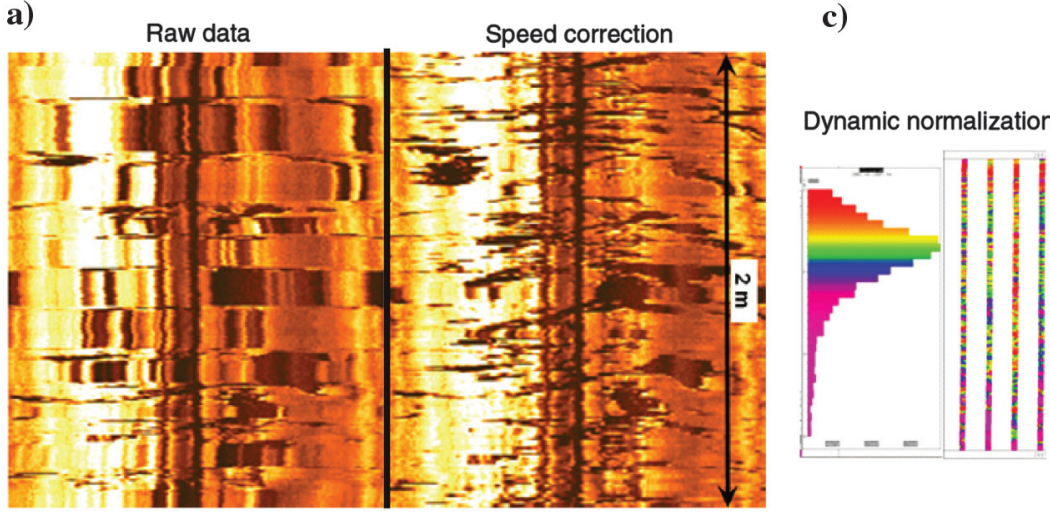

b)

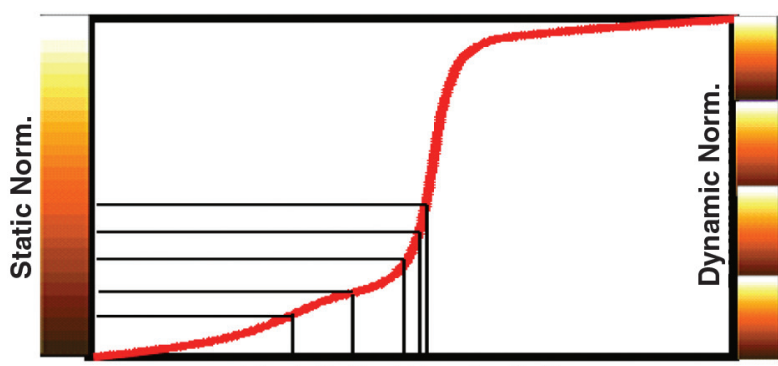

Resistivity / Conductivity

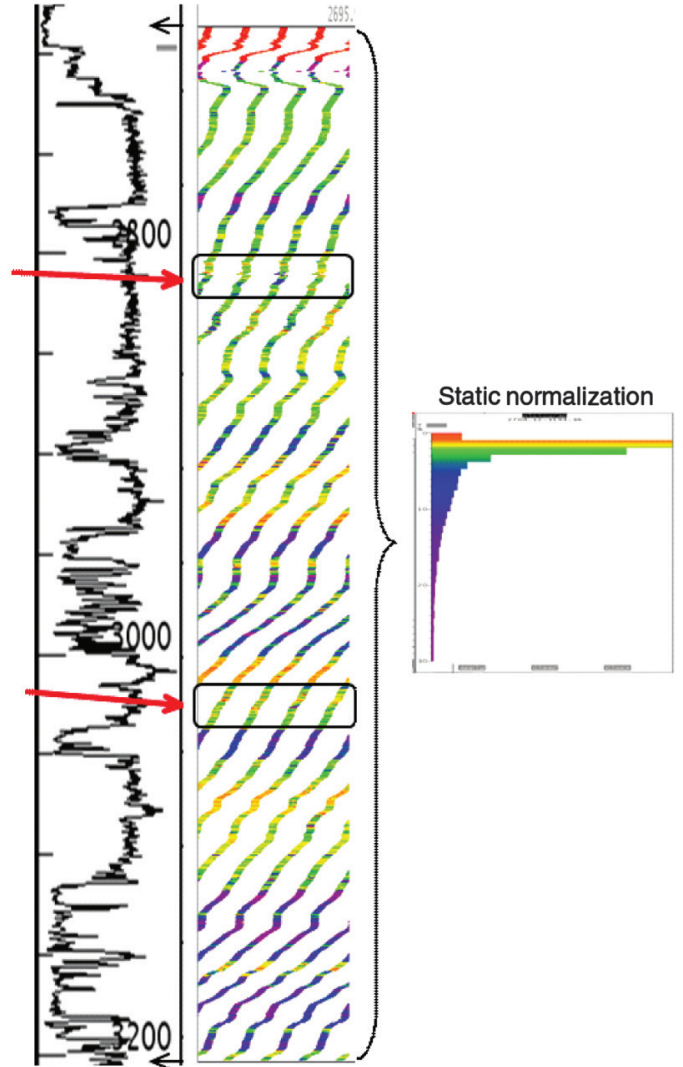

Figure 5. From resistivity to image logs. (a) The speed correction. Due to cable friction and pressure applied on the pad while logging, the cable speed at the surface may be stable while the imager tool does not have constant velocity. The data are regularly sampled in time but can have an irregular sampling in depth. The irregularities are due to cable elongation variations. This effect is clearly identified on the image by the compression interval, when the tool travels slower (e.g., due to sticking) or by the stretching interval, when the tool travels faster (e.g., due to a sudden release). The speed correction objective is to correct for erratic tool motions and time depth to convert the data. (b) Mapping color scales. The images are generated by mapping the resistivity curves with a color chart. (c) Static versus dynamic normalization. Static normalization uses one color scale for the whole logged section, and dynamic normalization uses the same color chart on a small interval moved with a regular step. On a "static" normalized image, any color change is representative of a petrophysical property formation change. A "dynamic" normalization enhances the details. 
The objective of this image log study was to perform an interpretation of the sedimentary facies and postdepositional deformations of the noncored intervals, based on the geologic and sedimentologic information extracted from the wireline imager tool. For that, an image log study included some important phases as follows:

1) Recording the raw field data from the imager tool and from conventional wireline logs (including a neural network-computed facies [NNCF]). At this stage, it is recommended to work on raw field acquisition records. It must be considered that any process is definitive and does not allow further reprocessing. A first-lithogical determination is made with the wireline logs. Such a determination is representative of the sand/shale content of the formation and quickly provides a global and stable response. The NNCF is based on clustering the log responses from different tools. The limits of such an electric lithofacies/NNCF model arise from the possible confusion between a formation with similar sand/shale ratios and the resolution limitations that can smear the signal between thin beds. Thanks to their high resolution and borehole wall coverage, image logs enable us to identify discontinuous and discordant sedimentary features (texture, structures, beds, and contacts) and postdepositional events (fractures, faults, erosional surfaces, diagenesis, burrowing, and fluid flows) - features that are not detected on standard open-hole logs.

2) Quality control of raw data: Because the image log data quality is largely dependent of the regularity of the tool motion and the borehole condition (rugosity), the tool dynamics and the hole geometry have to be checked. Confidence limits and visual quality checks of the images establish the reliability of the final interpretation. Table 2 summarizes all the curves and parameters to be checked.

3) Processing raw data to an image log: cutoff on anomalous resistivity values, correction of magnetic variation (if necessary), speed correction (Figure 5a), and static and dynamic normalization of microresistivity curves (Figure 5b).

4) Automatic correlations and calculation of dips: The dips are computed by correlation between pads, comparing the results in two windows of correlation interval-pitch-search angle $\left(1-0.5 \mathrm{~m}\right.$ to $75^{\circ}$ and $2-1 \mathrm{~m}$ to $75^{\circ}$; Schlumberger, 1985$)$. The interest of automatic correlation programs is fast in providing structural and stratigraphic dip trends. However, the results only represent average dip information over an restricted interval associated with the window sizes. For detailed dip analy-

sis, manual picking is preferred over the automatic methods in complex environments such as glaciogenic successions.

5) Endorsement of automatic correlations including manual elimination of inconsistent dips, comprehensive depth matching, consistency of results, recognition of artifacts, and computed horizon dips.

6) Analytical stage: inventory of sedimentary and structural features by interactive picking.

7) Lithologic interpretation based on cutting observations and the study of logs, core and side wall cores description, if available. Caution has to be taken because image logs are not lithologic logs; e.g., a high salt-water-bearing sandstone and shales might have the same response. Therefore, the interpreter needs a lithologic input and to use it as a backbone for the interpretation. Basically, the well geologic survey (called the mudlog or masterlog) is the favored geologic input in this study. This document provides the main lithology, grain size, calcimetry, cement, mud property, and drilling conditions. Cores and sidewall cores, if available, provide lithology, biologic indicators, hydrodynamic indications, oil shows, and more, but they are limited in length.

8) Sedimentary interpretation based on lithology, values of sedimentary dips, dip development (trends), and image analyses. The image log interpretation practice consists of picking the dip of major erosional surfaces and depositional surfaces. Emphasis is placed on the surface morphologies (whether even or not), beds (whether isopach or not), and facies transition (gradual or abrupt). These observations allow us to identify features such as parallel multilayer beds, chaotic events, erosive surfaces, structured features, or folds. In addition, a visual analysis of the image fabric, i.e., the observation of texture and internal structures, is done to extract the maximum sedimentary and geologic informa-

a)

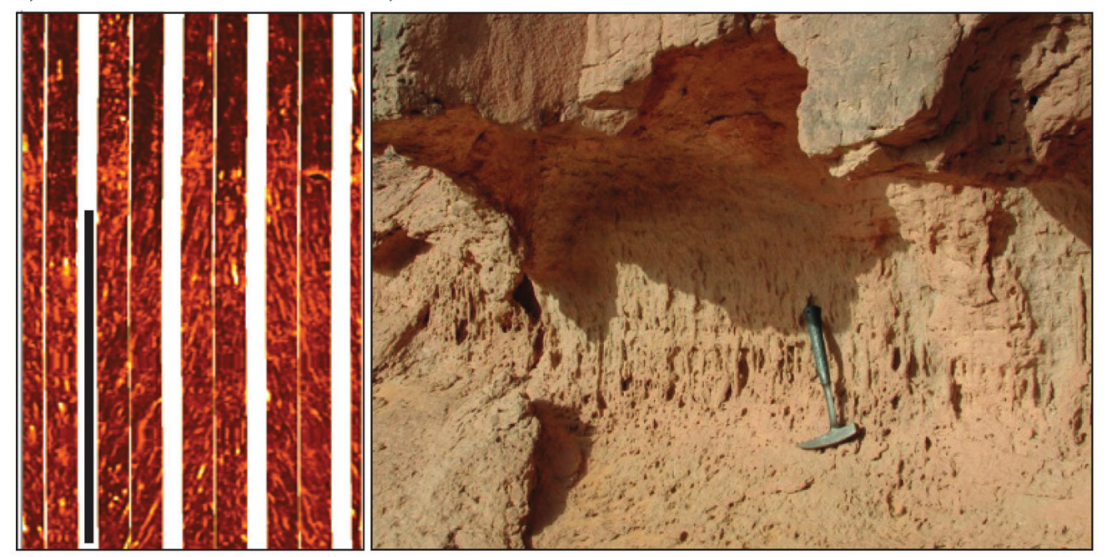

Figure 6. Tigillite facies (a skolithos ichnofacies) characterizing the preglacial Ash Shaybiyat Formation (Lower Ordovician) (a) on an FMI image and (b) on the outcrop (a supplementary animation of Figure 6a can be accessed through the following link: s1.mp4). The black tick is $50 \mathrm{~cm}$ on panel (a), and the hammer is approximately $30 \mathrm{~cm}$ on panel (b). Location of panel (a) in Figure 12. 
tion. This information concerns the relative grainsize changes (fining- or coarsening-upward trends) and the sorting. Bedding and lamination may be described, e.g., with a combination of these terms: parallel, curved, wavy, and continuous.

The last step of the workflow is critical in this study. The glacial successions of the Murzuq Basin contain

a)

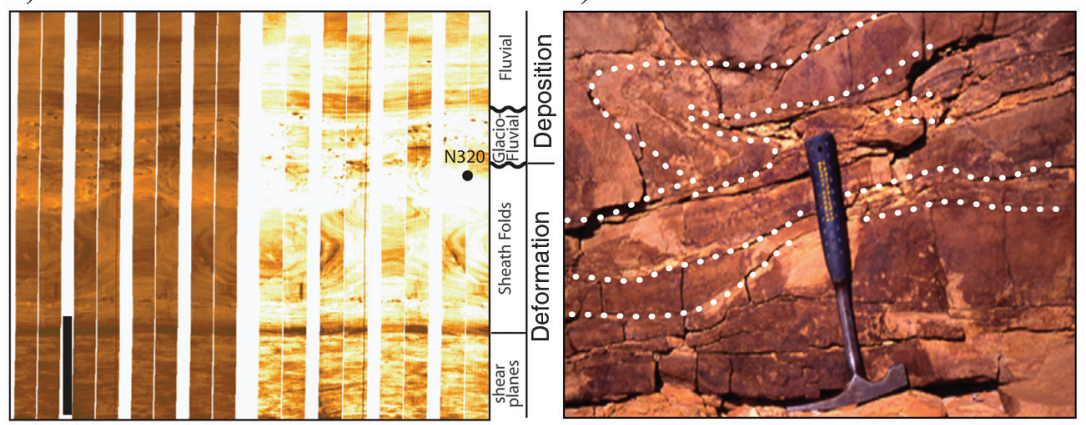

c)

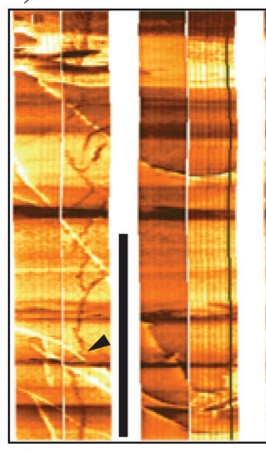

e)

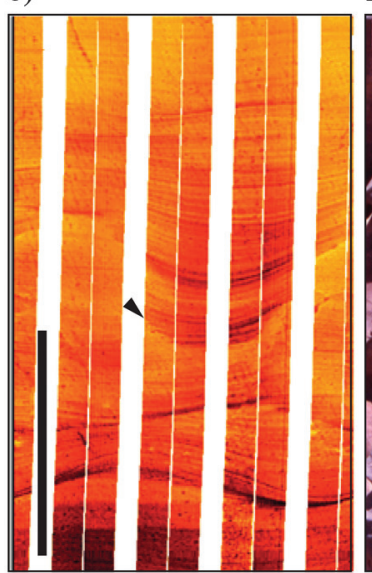

f)

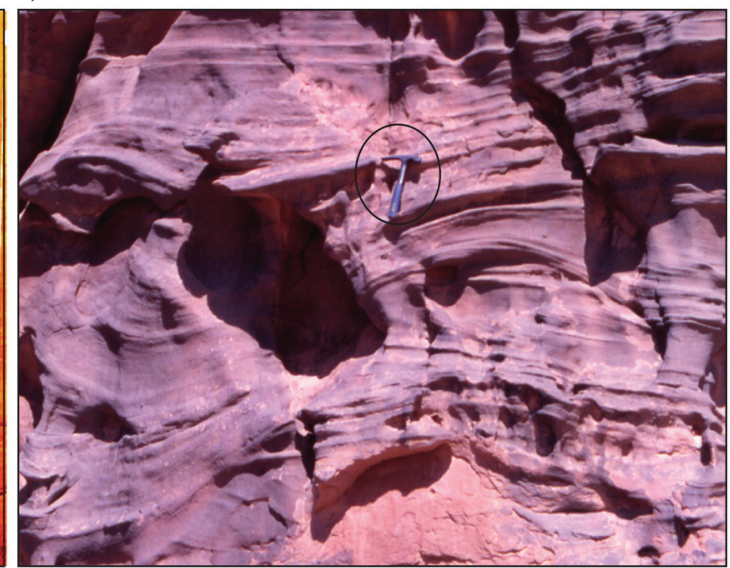

Figure 7. Examples of GA facies. (a) Deformation till resulting from ice-stream subglacial deformation (a supplementary animation of Figure 7a can be accessed through the following link: s2.mp4). The main characteristic is the presence of sheath folds that are elongated toward N320 (orientation of GA2; Moreau, 2005; Moreau et al., 2005). The sheath folds are underlain by shear planes and overlaid by coarse-grained subglacial deposits. (b) Example of a small sheath fold on the outcrop. Examples of subglacial step fractures (c) on the FMI and (d) on the outcrop marked by arrows. Example of chute and pool facies (eddy sedimentation) in a proglacial setting (e) on the FMI and (f) on the outcrop (a supplementary animation of Figure 7e can be accessed through the following link: s3.mp4). Notice the steepness of the scour surface (black arrow in panel [e]) and the

\section{Results \\ Identified depositional environments}

High-resolution borehole image log coupled with conventional logs provide an image sedimentary facies close to the geologic facies calibrated to the outcrop analogs. Based on the key sedimentologic observations from the outcrops, six resultant sedimentary depositional settings were defined in the well (Figures 6-11). The facies association succession and the glacial surface characteristics present a similar evolution as the Ghat area succession (Figures 2, 3, and 12; Table 1). The recognition of the glaciogenic stratigraphy results from the possibility of visually estimating the grain-size evolution and sorting.

1) Preglacial deposits (Ash Shaybiyat Formation; Figure 6): The Tigillites sandstones with their characteristic Skolithos ichnofacies (sand-filled worms burrow, simple vertical tube) mark the base of the studied succession (Radulović, 1984).

2) GA (Figure 7): A GA can be marked by subglacial deposits, glaciotectonic deformation, and proglacial sedimentation. Subglacial deposits are recognized by pebble- to gravel-sized and cross-stratified sandstones accumulations. The deformation structures within and under the GA are the best diagnosis to identify the glacial erosion surfaces. The deformation is marked by, sheath folds, intraformational shear planes, and step fractures (Figures 7 and 8a; Denis et al., 2010). The sheath folds are extremely good indicators of the ice flow direction. The subsurface and outcrop data give similar orientations for the glacial erosion surface associated with GA2 (N320, Figure 6a; Moreau, 2005). The density of step fractures is generally higher 
close to the glacial surface but can penetrate tens of meters under it (Figure 12). Orientation of step fractures, if they are associated with subglacial Riedel shears, can provide a good statistic estimation of the normal to the ice flow orientation. As in the outcrop, step fractures orientation can potentially be a good correlation tool between wells (Deynoux and Ghienne, 2004; Moreau et al., 2005). However, caution should be taken because step fractures form in other settings in association with compaction and gravity flows (e.g., the deltaic-fluvial transition in GS3; Figure 11). The proglacial sandstones can contain characteristic chute and pool facies related to very high energy flow conditions (Ghienne et al., 2010; Girard et al., 2012a, 2012b; Figure 7e and $7 f$ ).

3) Glaciomarine deposits (GS; Figure 8): The glaciomarine deposits directly cover the glacial erosion surfaces when the glacial depositional sequence is preserved (Figure 8c). The glaciomarine deposits are marked by diamictites. The diamictites are formed of a shaley to silty matrix with crude bedding and poor sorting containing isolated granule-size clasts (Figure 8b). The matrix supports isolated, thin, coarse-grained sandstone lenses and occasional pebbles and blocks (Figure 8a and 8b). The deposits are a rainout till with the matrix formed by the settling of turbid plumes surging from a marine-terminating ice sheet (Deynoux, 1985). The isolated clasts are IRD.

4) Deltaic deposits (GS; Figure 9): The facies association corresponds to stacked erosional fining- and thinning-upward sandstone sequences (containing successions of massive sandstones with outsized clasts, climbing megaripples, ripples, and planar lamination; Figure 9; Girard et al., 2012a, 2012b). This facies association is poorly developed in the Ghat area, but it is well exposed $100 \mathrm{~km}$ to the north (Ghienne et al., 2010; Girard et al., 2012a, 2012b). The deposits show alternations of turbiditic sequences and sandy mass flows. The turbiditic sequences can have a gradual contact with an underlying mass flow (Figure 9). The sequences are usually starting with 3D climbing dunes overlaid by planar climbing ripples and draped

a) with planar laminations occasionally containing dewatering structures (Figure 9). The mass flows are massive and can contain matrix-supported $<5 \mathrm{~cm}$ elongated clasts (Figure 9).

5) Fluvial deposits (GS; Figure 10): The depositional environment is marked by poorly sorted sandstone to conglomerate (basal lag). The deposits can be formed of meter-thick sequences with a basal scour

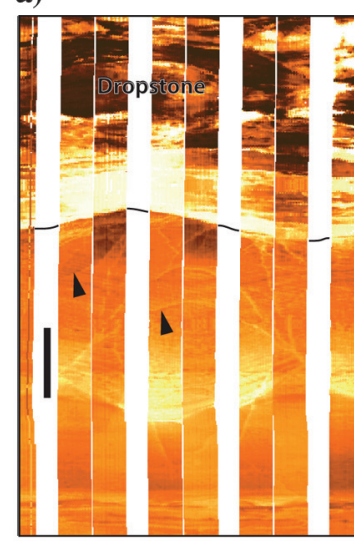

Figure 8. Example of glaciomarine deposition (rainout till). (a) Contact between the GA and the glaciomarine deposit marking the ice-sheet recession (postglacial deposition, GS). The black arrows point to step fractures; notice the large dropstone within the rainout till. (b) Regular Late Ordovician glaciomarine shales, "microconglomeratic" shales (Beuf et al., 1971). Large IRD such as the one in panel (a) are rare in the succession. Rather, the IRD are marked by granule-sized sand grains mixed with siltstones (diamictite) and isolated coarsegrained sand lenses (arrow). (c) Example of rainout till from the outcrop, the arrow points to a dropstone. Scales: black tick, $50 \mathrm{~cm}$; hammers, approximately $30 \mathrm{~cm}$. Location of panels (a and b) in Figure 12. a)

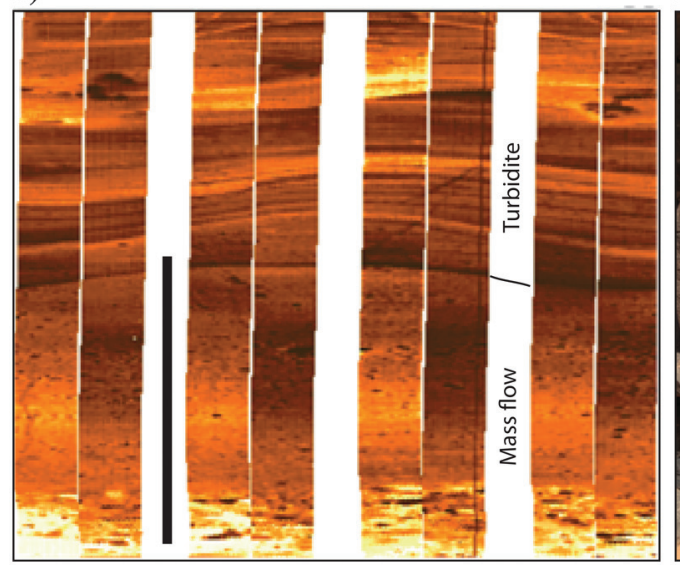

b)

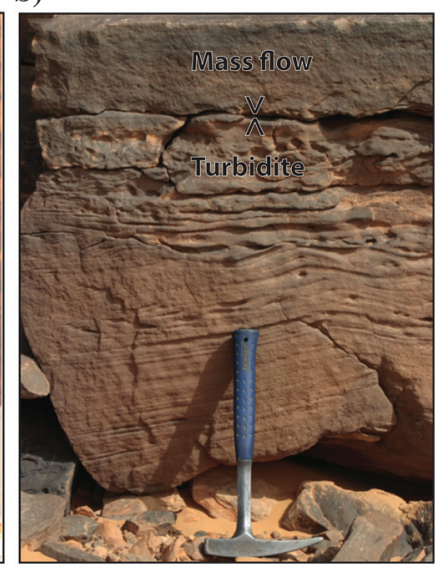

Figure 9. Example of deltaic facies from (a) the FMI imaging and (b) the outcrop. Two types of facies are observed: mass flow and "turbiditic" sequences (for more details, see Moreau, 2005; Girard et al., 2012a). The turbiditic sequences can be in continuity with the mass flows. If preserved, the sequences start with planar lamination (or very low angle planar cross-stratifications), 3D climbing dunes, 2D climbing dunes, climbing ripples, and planar laminations. Dewatering structures are common at the summit of the sequences and within the mass flows. Scales: black tick, $50 \mathrm{~cm}$; hammer, approximately $30 \mathrm{~cm}$. Location of panel (a) in Figure 12. 
surface and a fining-upward trend with planar to trough cross-stratifications as the main sedimentary structures (Figure 10a and 10b). Characteristic of this glaciogenic succession, large climbing dune accumulations with coarse-grained reactivation surfaces can be identified (Figure 10c and 10d; Ghienne et al., 2010; Girard et al., 2012a, 2012b). Intervals a)

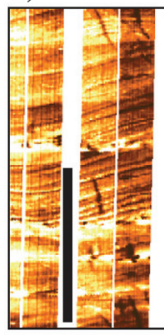

c)

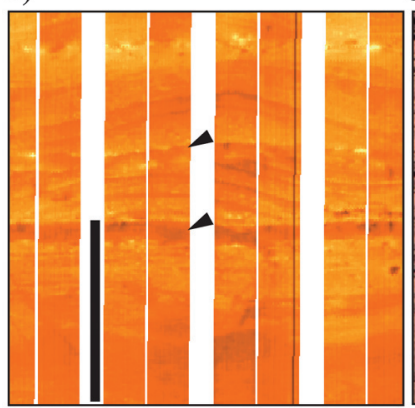

d)

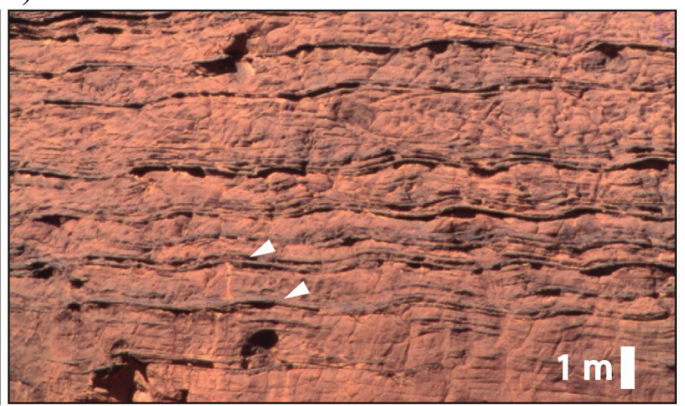

Figure 10. Examples of fluvial facies. Planar cross-bedding with basal coarsegrained lag (a) on the FMI and (b) on the outcrop. Fluvial climbing dunes accumulations characteristic of the glaciogenic succession (c) on the FMI and (d) on the outcrop. Notice the coarse-grained reactivation surfaces of these indrift bedforms (arrows, panels [c and d]; see more details in Ghienne et al., 2010). Scales: black tick, $50 \mathrm{~cm}$; hammer, approximately $30 \mathrm{~cm}$. Location of panel (a) in Figure 12 . a)

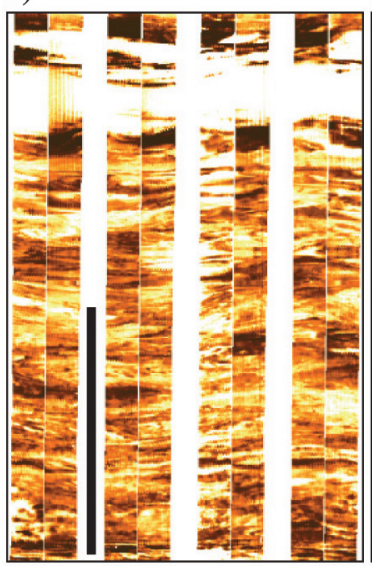

b)

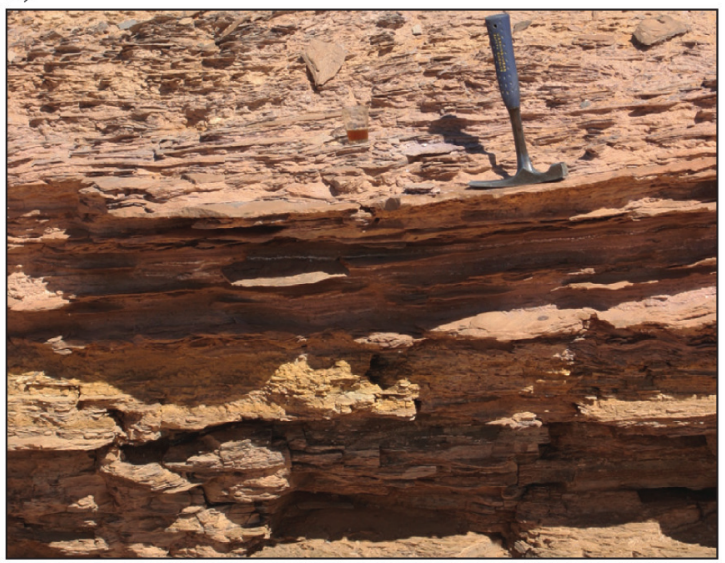

Figure 11. Example of interglacial deposits of TA1 (a) on the FMI and (b) on the outcrop. The deposit is characterized by flaser beddings, small hummocky crossstratifications, and bioturbations (Figure 12). TA marks the total withdrawal of the ice sheets from the basin and the end of direct ice activity. These surfaces are critical to establish the stratigraphy of the succession. Scales: black tick, $50 \mathrm{~cm}$; hammer, approximately $30 \mathrm{~cm}$. Location of panel (a) in Figure 12. with horizontal aggrading sand sheets mainly showing planar laminations with load casts and flame structures are also observed. Cross-bedding azimuth trends show a unidirectional flow direction individual set. The fluvial deposits are interpreted braided to low-sinuosity fluvial system with the channel fill marked by the cross-stratified units (including the climbing dunes) and the sand sheets as the flood plain (sandur; Ghienne et al., 2010; Girard et al., 2012a, 2012b).

6) TA (Figure 11): Within a shale matrix, the facies association contains fine-grained sandstone beds with symmetric ripples, flaser beddings, and mud drapes (Figure 11). Herringbone facies in coarse-grained sandstones also occur including mud chips at base of the ripples. The density of ichnofossils might locally be important. The TAs are particularly important because they form regional stratigraphic surfaces marking the end of the glacial cycles (Moreau, 2011).

\section{Comparison between the FMI and the outcrop data}

The borehole images illustrated most of the facies observed in the western Murzuq exposures (Figures 6-11). However, some differences remain when comparing the succession from the Ghat area (Figure 3) and from the well (Figure 12).

In general, the grain size and sorting are very comparable between the outcrop and the subsurface example, permitting us to establish the stratigraphy in the well. However, the well shows a $>325 \mathrm{~m}$ thick succession in which the Ghat glacial ridge succession does not exceed $200 \mathrm{~m}$. The Ash Shaybiyat Formation and the GA/GS2 are very similar between the well and the exposures. The GA2 shows the same orientation of ice flow as in the Ghat area. However, TA1 is more developed and finer grained in the well than in the Ghat area. The presence of flaser beddings and hummocky cross-stratifications (Figure 12) suggests the action of waves and thus a more open environment than in the Ghat area. GA3 is also thicker in the well and suggests an energetic, thick proglacial deposition in front of an advancing ice. In the outcrop, the glacial advance is only marked by an increasing amount of 
IRD at the base of GA3. The deltaic part of GS3 is similar in the two areas. However, GS3 contains a thick fluvial accumulation ( $>50 \mathrm{~m}$; Figure 12 ) that is not preserved in the Ghat area. From GA4 to TA2, the compared successions appear broadly similar in depositional environment.

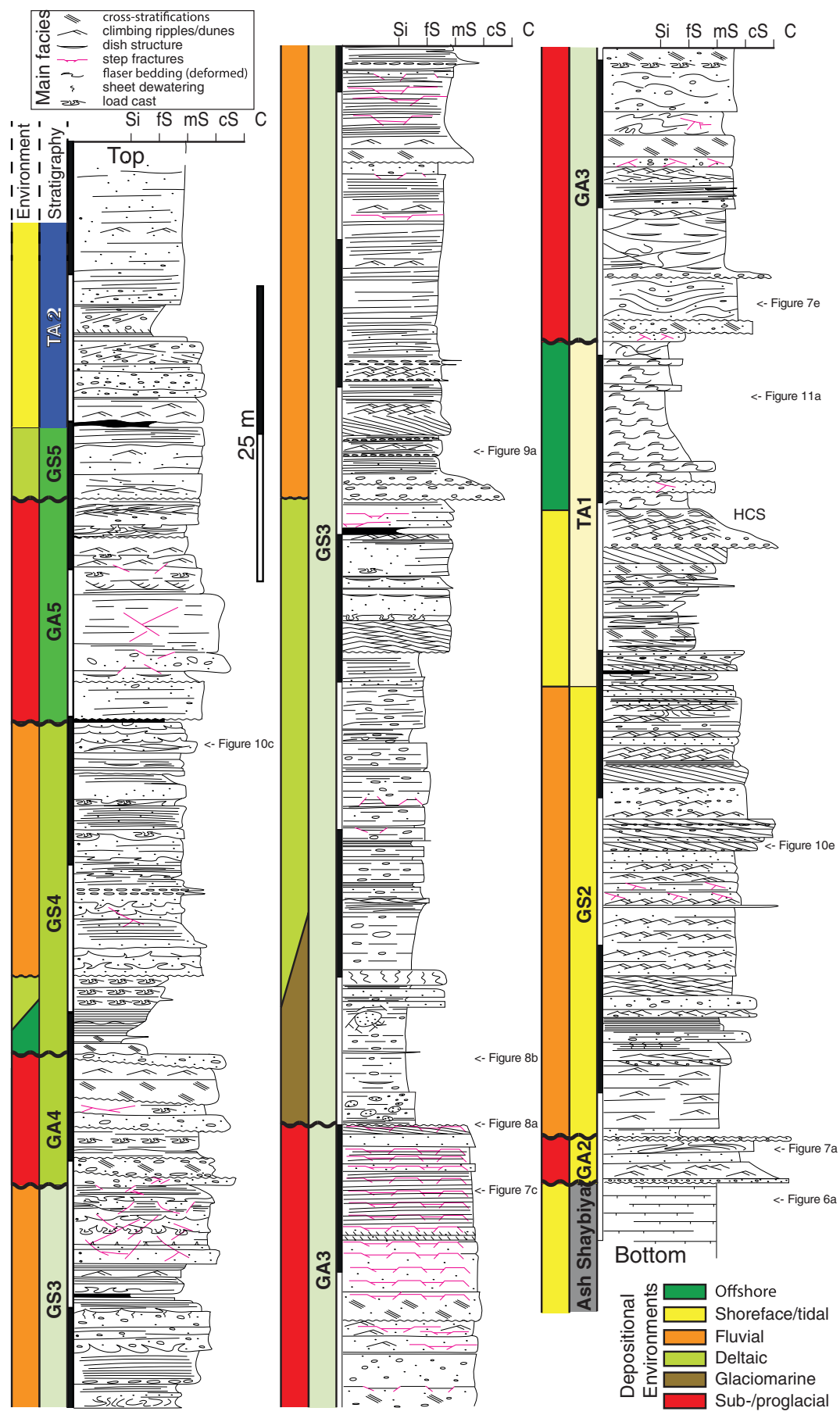

Figure 12. Sedimentary log established based on FMI imaging and resulting stratigraphic and paleoenvironmental reconstructions. Grain-sized estimations and sorting are obtained by direct observations (as in the outcrop). Facies interpretations issue from the architecture of the imaged stratifications and knowledge of the succession on the outcrop. Notice the penetration of the subglacial deformations under the erosive surfaces that helps in locating glacial erosion surfaces.
The well is in a similar paleogeographic setting to the Ghat area: It is under the repetitive influence of ice stream erosion within a regional depression formed by these incisions (Moreau, 2005, 2011; Moreau et al., $2005,2007)$. The well succession is showing a more open environment and a more developed succession, particularly in the middle of the sequence (TA1 and GA/GS3). It is suggested that the central position of the well within the $350 \mathrm{~km}$ wide depression favored more open or less restricted depositional environment compared with the Ghat area (Moreau et al., 2007).

\section{Conclusions}

After high-quality processing, observation of the evolution of imaged sedimentary facies and deformations allows comparison and correlations between well data and exposure. The quality of the imaging is such that the sedimentary logging information is of the same quality and even better (absence of cover/ exposure problem) for the well than at exposure. Glacial surfaces and transgressive intervals have been identified on borehole image logs, providing a reliable stratigraphy in the subsurface. Stratigraphic succession as determined by borehole image logs shows the same main glacial and sedimentologic features and can be precisely compared with the one described in the Ghat vicinity. Four glacial surfaces and two transgressive intervals have been identified on the basis of borehole image log interpretation. The glacial surfaces and associated deposits were identified from the deformation succession with step fractures and sheath folds. Glaciofluvial deposits are recognized by pebble accumulations or sandstone bedforms related to very high energy flow conditions. Major transgressive surface occurrences are outlined by the development of units including burrowing activity, flaser beddings, storm sequences, and possible tidal megaripples. Moreover, by analogy with outcrop data, bedform succession and relative grain-sized changes allow determining depositional environments of the glacial depositional sequences. The specific signature of the succession permits us to identify the evolution with, for example, (1) shaley to silty facies with poor bedding, thin sandstones lenses and isolated pebbles attributed to glaciomarine environments, (2) erosional fining- and thinning-upward sandstone sequences 
(containing successions of climbing megaripples, ripples, planar lamination) interpreted as deltaic facies association, and (3) meters thick trough to planar cross-bedded sandstones associated with aggrading sand sheets, probably equivalent to a flood plain, are coherent with fluvial facies observed into the Ghat exposed area.

High-resolution borehole image logs, combined with conventional logs and drill-site geologic reports, provide a sedimentary facies image directly comparable to the rocks exposed and allow the reconstruction of paleoenvironments. Once correctly calibrated, the borehole image log proved to be critical in the interpretation of glacial series by the induced improvement of the sequence stratigraphy definition and the reservoir architectures.

The borehole image logs provide a unique opportunity to correlate between wells at high resolution. Based on the outcrop analogs, this study provides solutions to overcome the common problems of relatively homogeneous signature of the glaciogenic rocks when using regular downhole geophysical tools. In addition, the FMI gives information on the ice-flow orientations, which in turn are reliable correlation parameters at reservoir scales even if the reservoir architecture is complex. It is expected that further similar studies on imaged Late Ordovician glaciogenics will permit us to better constrain the paleoglaciological and paleoenvironmental depositional settings of the Murzuq Basin, fundamentals of the Ordovician-Silurian petroleum play. To conclude, the borehole image log combined with outcrop analysis could become a critical asset for the research of new targets and for the evaluation of fields containing glaciogenic reservoirs.

\section{Acknowledgments}

The authors thank Total management for permission to publish this paper. We are grateful to our friends, colleagues, editor K. Marfurt, associate editor A. Amer, and three anonymous reviewers for their constructive comments on the manuscript.

\section{References}

Bellini, E., and D. Massa, 1980, A stratigraphic contribution to the Palaeozoic of the southern basins of Libya, in M. J. Salem, and M. T. Busrewil, eds., The geology of Libya: Academic Press 1, 3-56.

Beuf, S., B. Biju-Duval, O. de Charpal, P. Rognon, O. Gariel, and A. Bennacef, 1971, Les grès du Paléozoïque Inférieur au Sahara: Sédimentation et discontinuités, évolution structurale d'un craton: Technip, 464.

Biju-Duval, B., M. Deynoux, and P. Rognon, 1974, Essai d'interprétation des fractures en gradins observées dans les formations glaciaires précambriennes et ordoviciennes du Sahara: Revue de Géographie Physique et de Géologie Dynamique, 16, 503-512.

Blanpied, C., M. Deynoux, J.-L. Ghienne, and J.-L. Rubino, 2000, Late Ordovician glacially related depositional systems of the Gargaf Uplift (Libya) and comparisons with correlative deposits in the Taoudeni Basin (Mauritania), in M. A. Sola, and D. Worsley, eds., Geological exploration of the Murzuq Basin: Elsevier, 485-509.

Boote, D. R. D., D. D. Clark-Lowes, and M. W. Traut, 1998, Paleozoic petroleum systems of North Africa, in D. S. Macgregor, R. T. J. Moody, and D. D. ClarkLowes, eds., Petroleum geology of North Africa: Geological Society of London, Special Publications 132, 7-68.

Coward, M. P., and A. C. Ries, 2003, Tectonic development of North African basins, in T. Arthur, S. MacGregorDunca, and N. R. Cameron, eds., Petroleum geology of Africa; new themes and developing technologies: Geological Society of London, Special Publications 207, 61-83.

Denis, M., M. Guiraud, M. Konaté, and J.-F. Buoncristiani, 2010, Subglacial deformation and water-pressure cycles as a key for understanding ice stream dynamics: Evidence from the Late Ordovician succession of the Djado Basin (Niger): International Journal of Earth Sciences, 99, 1399-1425, doi: 10.1007/s00531009-0455-z.

Deynoux, M., 1985, Terrestrial or waterlain glacial diamictites? Three case studies from the Late Precambrian and Late Ordovician glacial drifts in West Africa: Palaeogeography, Palaeoclimatology, Palaeoecology, 51, 97141, doi: 10.1016/0031-0182(85)90082-3.

Deynoux, M., and J.-F. Ghienne, 2004, Late Ordovician glacial pavements revisited: A reappraisal of the origin of striated surfaces: Terra Nova, 16, 95-101, doi: 10.1111/j .1365-3121.2004.00536.x.

El-Ghali, M. A. K., K. G. Tajori, H. Mansurbeg, N. Ogle, and R. M. Kalin, 2006, Origin and timing of siderite cementation in Upper Ordovician glaciogenic sandstones from the Murzuq basin, SW Libya: Marine and Petroleum Geology, 23, 459-471, doi: 10.1016/j.marpetgeo.2006 .02 .002 .

Eschard, R., H. Abdallah, F. Braik, and G. Desaubliaux, 2005, The Lower Paleozoic succession in the Tassili outcrops, Algeria: Sedimentology and sequence stratigraphy: First Break, 23, 27-36.

Galeazzi, S., O. Point, N. Haddadi, J. Mather, and D. Druesne, 2010, Regional geology and petroleum systems of the Illizi-Berkine area of the Algerian Saharan Platform: An overview: Marine and Petroleum Geology, 27, 143-178, doi: 10.1016/j.marpetgeo.2008.10.002.

Ghienne, J.-F., K. Boumendjel, F. Paris, B. Videt, P. Racheboeuf, and H. A. Salem, 2007a, The Cambrian-Ordovician succession in the Ougarta Range (western Algeria, North Africa) and interference of the Late Ordovician glaciation on the development of the Lower Palaeozoic transgression on northern Gondwana: Bulletin of Geoscience, 82, 183-214, doi: 10.3140/bull.geosci.2007.03 .183. 
Ghienne, J.-F., M. Deynoux, G. Manatschal, and J.-L. Rubino, 2003, Palaeovalleys and fault-controlled depocentres in the Late-Ordovician glacial record of the Murzuq Basin (central Libya): Comptes Rendus Geosciences, 335, 1091-1100, doi: 10.1016/j.crte.2003.09 .010 .

Ghienne, J.-F., F. Girard, J. Moreau, and J.-L. Rubino, 2010, Late Ordovician climbing-dune cross-stratification: A signature of outburst floods in proglacial outwash environments?: Sedimentology, 57, 1175-1198.

Ghienne, J.-F., D. P. Le Heron, J. Moreau, and M. Deynoux, 2007b, The Late Ordovician glacial sedimentary system of the West Gondwana platform, in M. J. Hambrey, P. Christofferson, N. F. Glasser, and B. Hubbard, eds., Glacial sedimentary processes and products: International Association of Sedimentologists, Special Publications 39, 295-319.

Ghienne, J.-F., J. Moreau, L. Degermann, and J.-L. Rubino, 2013, Lower Palaeozoic unconformities in an intracratonic platform setting: Glacial erosion versus tectonics in the eastern Murzuq Basin (southern Libya): International Journal of Earth Sciences, 102, 455-482, doi: 10.1007/s00531-012-0815-y.

Girard, F., J.-F. Ghienne, and J.-L. Rubino, 2012a, Occurrence of hyperpycnal flows and hybrid event beds related to glacial outburst events in a Late Ordovician proglacial delta (Murzuq Basin, SW Libya): Journal of Sedimentary Research, 82, 688-708, doi: 10.2110/jsr.2012.61.

Girard, F., J.-F. Ghienne, and J.-L. Rubino, 2012b, Channelized sandstone bodies ("cordons") in the Tassili N'Ajjer (Algeria and Libya): Snapshots of a Late Ordovician proglacial outwash plain, in M. Huuse, J. Refern, D. Le Heron, R. J. Dixon, A. Moscariello, and J. Craig, eds., Glaciogenic reservoirs and hydrocarbon systems: Geological Society of London, Special Publications 368, 355-379.

Joubert, J.-B., J. Moreau, J.-F. Ghienne, and J.-L. Rubino, 2007, FMI characterisation of Late Ordovician glacial facies and surfaces: 3rd North Africa/Mediterranean Petroleum and Geosciences Conference and Exhibition, EAGE, Extended Abstracts.

Klitzsch, E., 1981, Lower Palaeozoic rocks of Libya, Egypt, and Sudan, in C. H. Holland, ed., Lower Palaeozoic of the Middle East, Eastern and Southern Africa, and Antarctica: John Wiley \& Sons, 131-163.

Le Heron, D. P., and J. Craig, 2008, First-order reconstructions of a Late Ordovician Saharan ice sheet: Journal of the Geological Society of London, 165, 19-29, doi: 10 .1144/0016-76492007-002.

Le Heron, D., O. Sutcliffe, K. Bourgig, J. Craig, C. Visentin, and R. Whittington, 2004, Sedimentary architecture of Upper Ordovician tunnel valleys, Gargaf Arch, Libya: Implication for the genesis of a hydrocarbon reservoir: Geoarabia, 9, 137-159.

Le Heron, D. P., O. E. Sutcliffe, R. J. Whittington, and J. Craig, 2005, The origins of glacially related soft- sediment deformation structures in Upper Ordovician glaciogenic rocks: Implication for ice-sheet dynamics: Palaeogeography, Palaeoclimatology, Palaeoecology, 218, 75-103, doi: 10.1016/j.palaeo.2004.12.007.

Lüning, S., J. Craig, J. K. Loydell, P. Storch, and W. R. Fitches, 2000, Lower Silurian "hot shales" in North Africa and Arabia: Regional and depositional model: Earth-Science Reviews, 49, 121-200.

Lüning, S., Y. M. Shahin, J. K. Loydell, H. T. Al-Rabi, A. Masri, B. Tarawneh, and S. Kolonic, 2005, Anatomy of a world-class source rock: Distribution and depositional model of Silurian organic-rich shales in Jordan and implications for hydrocarbon potential: AAPG Bulletin, 89, 1397-1427, doi: 10.1306/05250505014.

Moreau, J., 2005, Stratigraphical architecture and dynamic of Ordovician glacial deposits into the Murzuq Basin, Libya: Ph.D. thesis, Strasbourg University, 192.

Moreau, J., 2011, The Late Ordovician deglaciation sequence of the SW Murzuq Basin (Libya): Basin Research, 477-449,23, doi: 10.1111/j.1365-2117.2010.00499.x.

Moreau, J., L. Degermann, J. F. Ghienne, and J. L. Rubino, 2007, Large-scale physiography of the Murzuq Basin shelf during Hirnantian ice-sheet final retreat and Silurian transgression: Outcrops and seismic interpretations: 3rd North Africa/Mediterranean Petroleum and Geosciences Conference and Exhibition, EAGE, Extended Abstracts.

Moreau, J., and J. F. Ghienne, forthcoming, Cross-shelf trough and ice-stream lineations in the Sahara (Late Ordovician, Murzuq Basin, Libya), in J. A. Dowdeswell, M. Canals, M. Jakobsson, B. J. Todd, E. K. Dowdeswell, and K. A. Hogan, eds., Atlas of submarine glacial landforms: Modern, Quaternary and ancient: Geological Society, London, Memoirs, 46, doi: 10.1144/M46.

Moreau, J., J.-F. Ghienne, D. P. Le Heron, J.-L. Rubino, and M. Deynoux, 2005, $440 \mathrm{Ma}$ ice stream in North Africa: Geology, 33, 753-756, doi: 10.1130/G21782.1.

Radulović, P., 1984, Explanatory booklet for the geological map of Libya, Sheet Wadi Ghat, NG32-15: Industrial Research Centre, scale 1:250,000.

Schlumberger, 1985, Pendagemétrie: Interprétation: Schlumberger, 76

Štorch, P., and D. Massa, 2006, Middle Llandovery (Aeronian) graptolites of the western Murzuq Basin and $\mathrm{Al}$ Qarqaf Arch region, south-west Libya: Palaeontology, 49, 83-112, doi: 10.1111/j.1475-4983.2005.00530.x.

Sutcliffe, O. E., J. A. Dowdeswell, R. J. Whittington, J. N. Theron, and J. Craig, 2000, Calibrating the Late Ordovician glaciation and mass extinction by the eccentricity cycles of Earth's orbit: Geology, 28, 967-970.

Torsvik, T. H., and L. R. M. Cocks, 2013, Gondwana from top to base in space and time: Gondwana Research, 24, 999-1030, doi: 10.1016/j.gr.2013.06.012. 


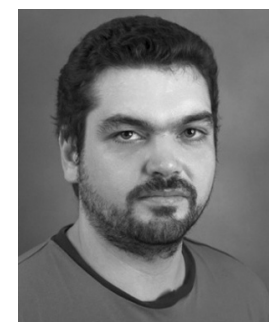

Julien Moreau received a Ph.D. (2005) in sedimentology at the University of Strasbourg, working on the Libyan record of the Late Ordovician glaciation. He has been as assistant professor in applied geophysics at the University of Copenhagen since 2012. He worked in several European Universities as a postdoctoral researcher (Strasbourg, Aberdeen, Manchester, Mines-ParisTech, and Helsinki). His research focuses on the study of sedimentary basins, blending geology and geophysics from data acquisition, processing, and interpretation to modeling. Most of his research intends to improve imaging and models of intricate systems, mainly focusing on sedimentary processes. He has specialized in high palaeolatitude basins that hosted ice sheets during the Ordovician, the Late Palaeozoic, and the Pleistocene ice ages.

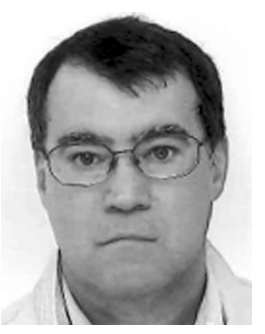

Jean-Bernard Joubert received a degree (1979) of geologist explorer in Nancy. He is a sedimentologist in charge of borehole imaging studies for Total in the scientific and technical centre of Pau (France). He joined the Societé Nationale Elf Aquitaine Production (SNEAP) first as a mining geologist until 1985 and then as an operation geologist until 1995. Since then he became a sedimentologist in charge of borehole imaging studies in SNEAP and then in Total when the both companies merged in 2000. 